\title{
Variation in Fatty Acid Composition of Sarcina flava Membrane Lipid with the Age of the Bacterial Culture
}

\author{
By M. I. S. HUNTER AND D. THIRKELL \\ Department of Biochemistry, University of St Andrews, North Street, \\ St Andrews, Fife
}

(Accepted for publication 15 December 1970)

Variations in the composition of the growth medium (Kaneda, 1966; Edmonds \& Cooney, 1969), availability of oxygen (White \& Frerman, 1968), temperature (Daron, I970) and age of the culture (Kaneda, I966; Knivett \& Cullen, I967) each effected marked alterations in the profiles of fatty acid extractable from the whole bacteria. We have now determined the effect of the age of the culture on the fatty acid compositions of three membrane lipid fractions from Sarcina flava.

A 400 l. culture of Sarcina flava (NCTC 7503) was grown at $34^{\circ}$ in nutrient broth (Oxoid Ltd) $+\mathrm{I} \%$ glucose. Half the culture was harvested at $24 \mathrm{~h}$. (exponential phase) and the remainder at $57 \mathrm{~h}$. (stationary phase). The membranes were prepared by the method of Salton \& Freer (1965) and lyophilized. Portions (I g.) were moistened and the lipids extracted according to the flow chart on p. II6; this scheme gave three fractions: (i) free lipid, (ii) acid hydrolysate, and (iii) base hydrolysate. Fractions (ii) and (iii) represented bound lipid. All fractions were taken into chloroform + methanol $(2+I, v / v)$, washed by the procedures of Folch, Lees \& Sloane-Stanley (1957) and lyophilized to constant weight. To prepare methyl esters for gas-liquid chromatography, (g.l.c.) each fraction was first saponified in $10 \%$ (w/v) methanolic $\mathrm{KOH}$ overnight at $20^{\circ}$. The saponification mixtures were extracted three times with diethyl ether. The aqueous layers were then acidified to $\mathrm{pH} 2$ with $\mathrm{HCl}$ and extracted with diethyl ether, dried over anhydrous sodium sulphate and taken to dryness in vacuo. The acids were esterified with $\mathrm{BF}_{3}+$ methanol (British Drug Houses Ltd). Dried esters in diethyl ether were concentrated prior to analysis. Reduction of the esters was carried out in absolute ethanol at $20^{\circ}$ in an atmosphere of pure hydrogen over a palladium/charcoal catalyst for $30 \mathrm{~min}$.; the esters were then re-extracted into diethyl ether. For g.l.c. analysis of the fatty acid methyl esters, I $\mu 1$. portions were separated on a Pye model IO4 gas chromatograph on $5 \mathrm{ft}$ long stainless steel columns containing either $(a) 10 \%$ diethyleneglycol succinate (DEGS) or (b) $5 \%$ Apiezon L (APL). Analyses were performed isothermally at either $190^{\circ}$ (DEGS) or $215^{\circ}$ (APL) and each run allowed to continue for $90 \mathrm{~min}$. The fatty acids were tentatively characterized using plots of carbon numbers versus logarithms of retention times for known standards (B.D.H. Ltd) and by comparing retention values with those previously reported by Burchfield \& Storrs (1962) for both the polar and non-polar columns. Those unsaturated acids that were present were identified by comparison of retention times before and after reduction. The proportions of the fatty acids in any one fraction were estimated by relating the individual peak areas to the total area. Fatty acids constituting less than $1 \%$ of the total were recorded as being present in trace amounts. 


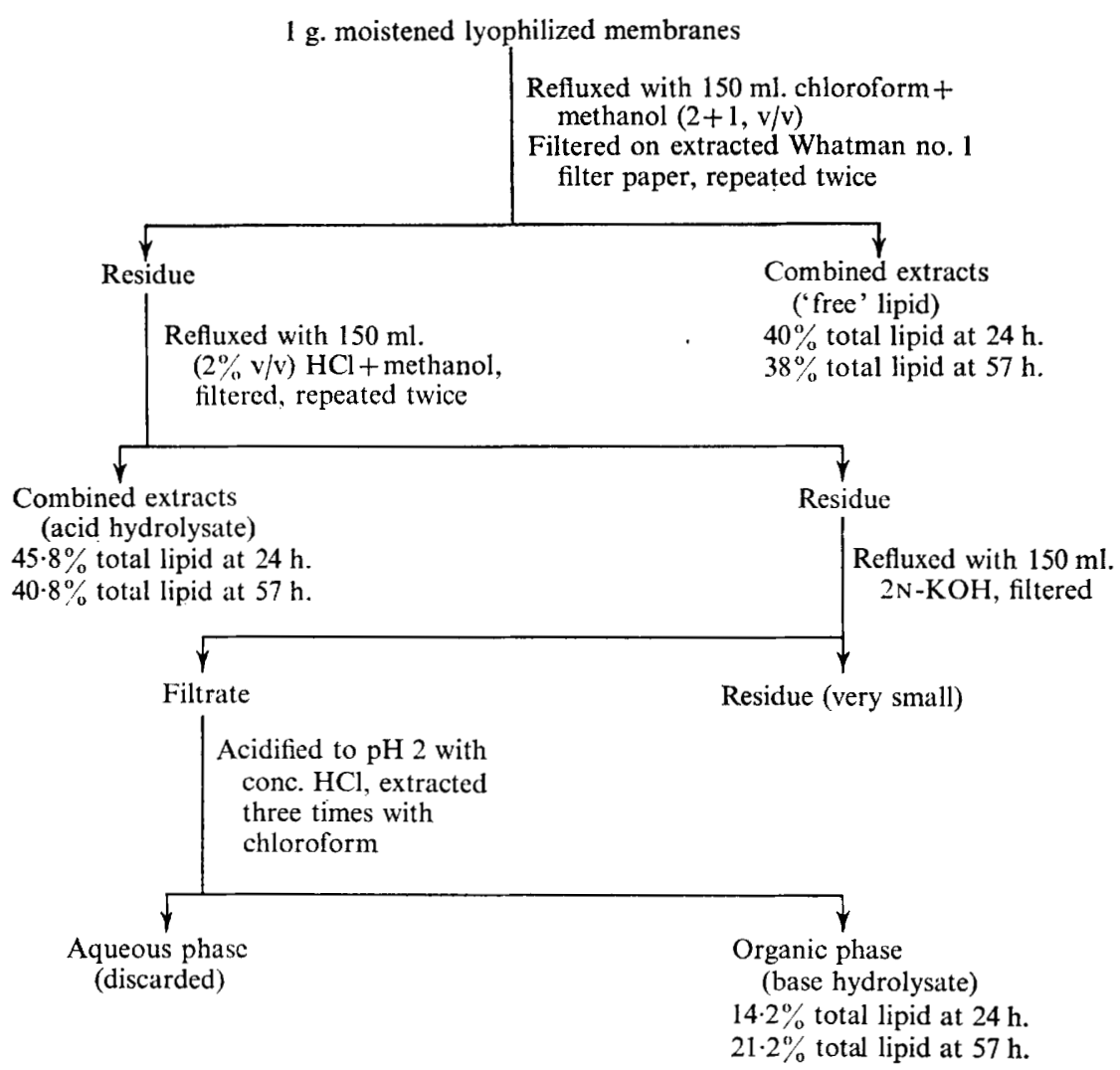

Total extractable lipid accounted for $19.6 \%$ by weight (corrected for moisture and ash) of the organic material of the membranes from bacteria cultured both for 24 and $57 \mathrm{~h}$. The fatty acid compositions of the three fractions from the two membrane preparations are shown in Table $\mathrm{I}$. Several peaks on the chromatogram could not be identified unequivocally by the methods used, and, where present, have been represented by their apparent carbon numbers on the DEGS column and placed in brackets. These components are not unsubstituted straight chain, iso- or anteiso-, saturated or unsaturated fatty acids, but may have other substituents such as hydroxyl groups or ring systems. The latter have been shown in Escherichia coli (Knivett \& Cullen, 1965), Serratia marcescans (Law, Zalkin \& Kaneshiro, 1963), Agrobacterium tumefaciens (Law et al. 1963), and Lactobacillus arabinosus (Croom \& McNeil, 196I) and in each case the proportion of these acids in the whole cell varied with the cultural age.

The major fatty acid of the free lipid was a saturated branched $C_{15}$ acid whilst that of both hydrolysed fractions was a saturated straight chain $C_{17}$ acid, suggesting that the free lipid may be a different class of lipid from the other two fractions. Only small traces of unsaturated acids were detected, a finding in agreement with previous work reported for other species (Kaneda, 1963; Tornabene, Gelpi \& Oro, I967).

Using the carotenoids of the membrane as 'markers', the extraction procedures used did not remove all the membrane lipids. During the hydrolytic extractions, some losses were sustained by the formation of water-soluble degradation products, e.g. 
choline, serine, phosphoric acid and glycerol. Thus the figures quoted for the amount of lipid in the fractions are almost certainly less than the true values.

The main component of the free lipid, a branched saturated $\mathrm{C}_{15}$ compound, has been reported as the major fatty acid in several bacterial species (Akashi \& Saito, I960; Cho \& Salton, I966; Albro \& Dittmer, 1969). The proportion of the major fatty

Table I. Fatty acid composition of lipid fractions from Sarcina flava membranes

The figures are expressed as percentages.

\begin{tabular}{|c|c|c|c|c|c|c|}
\hline \multirow[b]{2}{*}{ Fatty acid } & \multicolumn{2}{|c|}{ Free lipid } & \multicolumn{2}{|c|}{ Acid hydrolysate } & \multicolumn{2}{|c|}{ Base hydrolysate } \\
\hline & $24 \mathrm{~h}$. & $57 \mathrm{~h}$. & $24 \mathrm{~h}$. & $57 \mathrm{~h}$. & $24 \mathrm{~h}$. & $57 \mathrm{~h}$. \\
\hline Br. 8:0 & - & - & - & Trace & - & - \\
\hline $8: 0$ & Trace & Trace & $1 \cdot 8$ & Trace & $I \cdot 2$ & Trace \\
\hline $8: I$ & - & Trace & - & Trace & - & - \\
\hline Br. 9:0 & - & - & $6 \cdot 7$ & - & - & - \\
\hline 9:0 & Trace & - & - & - & 一 & - \\
\hline 10:0 & $3 \cdot 2$ & 0.8 & $I \cdot 8$ & - & $4 \cdot 4$ & $1 \cdot 4$ \\
\hline 10:I & - & $3 \cdot I$ & - & $1 \cdot 6$ & - & - \\
\hline Br. II:0 & $2 \cdot 3$ & - & - & - & - & - \\
\hline II:O & - & - & $2 \cdot 0$ & $I \cdot 7$ & $I \cdot 3$ & Trace \\
\hline II : I & Trace & Trace & - & - & - & - \\
\hline$(I I \cdot I)$ & - & - & $4: 3$ & - & - & - \\
\hline Br. 12:0 & Trace & $2 \cdot I$ & - & - & $3 \cdot 3$ & - \\
\hline$(12.3)$ & - & - & - & 15.6 & - & - \\
\hline Br. $13: 0$ & $4 \cdot 9$ & $3 \cdot 2$ & - & - & - & - \\
\hline $13: 0$ & - & - & $2 \cdot 2$ & $1 \cdot 0$ & $\mathbf{I} \cdot \mathbf{I}$ & Trace \\
\hline Br. 14:0 & $4 \cdot I$ & $2 \cdot 3$ & $1 \cdot 0$ & Trace & $10 \cdot 8$ & $8 \cdot 3$ \\
\hline I4:0 & I.o & $1 \cdot 8$ & $3 \cdot 7$ & 4.4 & $4 \cdot 1$ & $2 \cdot I$ \\
\hline Br. $15: 0$ & $46 \cdot 3$ & $20 \cdot 6$ & 8.6 & $I \cdot 5$ & $3 \cdot 2$ & II. 4 \\
\hline $15: 0$ & - & - & $2 \cdot 6$ & $4 \cdot 2$ & $I \cdot 2$ & $1 \cdot 2$ \\
\hline$(15.2)$ & - & - & - & - & $I \cdot I$ & - \\
\hline Br. $16: 0$ & $I \cdot I$ & Trace & $x \cdot 0$ & $1 \cdot 6$ & Trace & Trace \\
\hline $16: 0$ & $5 \cdot 2$ & $9 \cdot 8$ & - & II $\cdot 7$ & $7 \cdot 3$ & $5 \cdot 7$ \\
\hline Br. $17: 0$ & Trace & $2 \cdot 4$ & 14.4 & $3 \cdot 3$ & $\mathrm{I} \cdot 6$ & I3.5 \\
\hline $17: 0$ & $2 \cdot 9$ & 15.0 & $22 \cdot 0$ & $22 \cdot 4$ & $19 \cdot 7$ & 20.9 \\
\hline Br. 18:0 & - & Trace & $I \cdot 7$ & - & $I \cdot 3$ & $1 \cdot 1$ \\
\hline $18: 0$ & 4.4 & $9 \cdot 3$ & 6.9 & $3 \cdot I$ & 3.8 & $2 \cdot 2$ \\
\hline (18.2) & & - & - & - & $I \cdot 2$ & - \\
\hline Br. $19: 0$ & Trace & $3 \cdot 0$ & $10 \cdot 0$ & $2 \cdot 4$ & $2 \cdot 4$ & $3 \cdot 9$ \\
\hline I9:0 & - & $I \cdot 4$ & $3 \cdot 0$ & $2 \cdot I$ & $I \cdot \mathbf{I}$ & Trace \\
\hline$(19.3)$ & - & - & - & - & $1 \cdot 2$ & $1 \cdot 2$ \\
\hline Br. 20:0 & - & Trace & $I \cdot 7$ & - & $1 \cdot 6$ & Trace \\
\hline $20: 0$ & - & $2 \cdot 0$ & $3 \cdot I$ & $\mathrm{I} \cdot 9$ & 1.8 & $\mathbf{I} \cdot \mathbf{I}$ \\
\hline$(20.3)$ & 3.6 & - & - & - & - & - \\
\hline Br. $21: 0$ & 5.0 & - & - & - & Trace & - \\
\hline $2 x: 0$ & $4 \cdot 5$ & - & - & - & $4 \cdot 2$ & $2 \cdot 2$ \\
\hline$(21.2)$ & $6 \cdot 7$ & $5 \cdot 0$ & - & - & - & - \\
\hline Br. 22:0 & $I \cdot I$ & - & $I \cdot 2$ & $10 \cdot 7$ & $I \cdot 9$ & - \\
\hline$(22.3)$ & $1 \cdot 7$ & $1 \cdot 4$ & - & - & - & - \\
\hline Br. 23:0 & Trace & $4 \cdot 4$ & Trace & $6 \cdot 5$ & $10 \cdot 9$ & $3 \cdot 7$ \\
\hline $23: 0$ & - & - & - & - & $3 \cdot 0$ & 3.0 \\
\hline$(23.2)$ & - & 6.I & - & - & $3 \cdot 0$ & $11 \cdot 7$ \\
\hline Br. 24:0 & - & $2 \cdot 0$ & Trace & - & - & - \\
\hline Recovery* & $98 \cdot 0$ & $95 \cdot 7$ & $99 \cdot 7$ & $97 \cdot 7$ & $97 \cdot 7$ & $94 \cdot 6$ \\
\hline
\end{tabular}

* Recoveries do not include acids with a concentration of less than I \%. Br. = Branched chain fatty acid. 
acid of the two bound fractions ( $17: 0$ ) remained almost constant with the age of the culture, whereas the proportion of the main component of the free lipid (br. 15:0) was more than halved in the membranes from organisms obtained from the $57 \mathrm{~h}$. culture. The considerable variation in membrane fatty acid composition with cultural age in Sarcina flava would seem to indicate a high turnover of the acids, and alteration of the acid profiles would cast doubt on the usefulness of using such profiles as a taxonomic criterion, as suggested by Moss, Dowell, Lewis \& Schekter (1967) and Kaneda (1967).

D. T. is grateful to the Science Research Council for financial support.

\section{REFERENCES}

AKashi, S. \& SATTO, K. (1960). A branched, saturated C 15 acid (sarcinic acid) from Sarcina phospholipids and a similar acid from several microbial lipids. Journal of Biochemistry 47, 222-229.

AldRo, P. W. \& DiTtMER, J. C. (1969). The biochemistry of long chain non-isoprenoid hydrocarbons. I. Characterization of the hydrocarbons of $S$. lutea and the isolation of possible intermediates of biosynthesis. Biochemistry 8, 394-404.

BưRCHFIELD, H. P. \& STORRs, E. E. (1962). Biochemical Applications of Gas Chromatography, pp. 549554. New York and London: Academic Press.

Chо, K. Y. \& Salton, M. R. J. (1966). Fatty acid composition of bacterial membrane and wall lipids. Biochimica et biophysica acta 116, 73-79.

Croom, J. A. \& MCNeIL, J. J. (I96I). The long chain fatty acids of certain biotin-requiring bacteria. Bacteriological Proceedings p. 170.

Daron, H. (1970). Fatty acid composition of lipid extracts of a thermophilic Bacillus species. Journal of Bacteriology ror, I45-15I.

EDMONDS, P. \& COONEY, J. J. (1969). Lipids of $P$. aeruginosa grown on hydrocarbons and in tryptic soy broth. Journal of Bacteriology 98, 16-22.

Folch, J., Lees, M. \& SlOANe-Stanley, G. H. (1957). A simple method for the isolation and purification of total lipids from animal tissues. Journal of Biological Chemistry 226, 497-509.

KANEDA, T. (1963). Biosynthesis of branched chain fatty acids. I. Isolation and identification of fatty acids from B. subtilis (ATCC 7059). Journal of Biological Chemistry 238, I222-1 228.

KANEDA, T. (I966). Biosynthesis of branched chain fatty acids. IV. Factors affecting relative abundance of fatty acids produced by B. subtilis. Canadian Journal of Microbiology 12, 501-514.

KANEDA, T. (1967). Fatty acid in the genus Bacillus. I. Iso- and anteiso- fatty acids as characteristic constituents of lipids in ten species. Journal of Bacteriology 93, 894-903.

KNIVETt, V. A. \& Cullen, J. (1965). Some factors affecting cyclopropane acid formation in E. coli. Biochemical Journal 96, 77I-776.

KNIVETt, V. A. \& Cullen, J. (1967). Fatty acid synthesis in E. coli. Biochemical Journal 103, 299-306.

LAW, J. H., Zalkin, H. \& Kaneshiro, T. (1963). Transmethylation reactions in bacterial lipids. Biochimica et biophysica acta 70, I43-151.

Moss, C. W., Dowell, V. R., LewIS, V. J. \& SCHeKTER, M. A. (1967). Cultural characteristics and fatty acid composition of C. acnes. Journal of Bacteriology 94, 1300-1305.

Salton, M. R. J. \& Freer, J. H. (1965). Composition of the membranes isolated from several Gram-positive bacteria. Biochimica et biophysica acta 107, $53 \mathrm{I}-538$.

TORNABENE, T. G., GeLPI, E. \& ORO, J. (1967). Identification of fatty acids and aliphatic hydrocarbons in $S$. lutea by gas chromatography and combined gas chromatography-mass spectrometry. Journal of Bacteriology 94, 333-343.

White, D. C. \& Frerman, F. E. (1968). Fatty acid composition of the complex lipids of $S$. aureus during the formation of the membrane-bound electron transport system. Journal of Bacteriology 95, 2198-2209. 